\title{
Seasonal Variation of Calving in Murrah Buffalo in different Agro Climatic Zones of Uttar Pradesh, India
}

\author{
V.V. Potdar*, J.R. Khadse, S.A. Joshi, Y.S. Gaundare, \\ Marimuthu Swaminathan, N.L. Phadke and A.B. Pande
}

BAIF Development Research Foundation, Central Research Station, Pune 412 202, India

*Corresponding author

\section{A B S T R A C T}

Keywords

Buffalo, Caving,

Agro climatic zones

Article Info

Accepted:

12 April 2019

Available Online:

10 May 2019

The present study was carried out to estimate seasonal variation of calving in Murrah buffaloes. The study was conducted in Central plain of Uttar Pradesh (Etah and Unnao), Mid-western plain of Uttar Pradesh (Bareilly) and Western plain zone Uttar Pradesh (Meerut) of India on 2828Murrah buffaloes theses buffaloes were inseminated during June 2010 to December 2014at BAIF's field Artificial Insemination centers which provide door-step artificial insemination service at villages level. The result indicated that calving of Murrah buffaloes occurred throughout year. In Central plain of Uttar Pradesh maximum calving observed in October month $18.70 \%$ \& August $15.44 \%$. In Mid-western plain of Uttar Pradesh maximum calving observed in October month $17.59 \%$ \& December $14.54 \%$ while in Western plain zone Uttar Pradesh maximum calving observed in August month $23.48 \%$ \&October $17.39 \%$.On the basis of season majority of calving observed between July to January months. It can be concluded that Murrah buffaloes have tendency to calve more in the days with shorter photoperiod as compare to days with longer photoperiod.

\section{Introduction}

The estimate of world buffalo population is approximately 185.29 million dispersed in 42countries, out of which 97\% (179.75 million) are found only in Asia. According to 19th Livestock Census 2012 it has reached upto 108.7 millions India has approximately $57 \%$ (108.7 million) of the total world buffalo population. The water buffalo contributes immensely to the agricultural economy through milk, meat, hides and draught power. Share of buffalo milk occupies the highest position in Indian dairy industry, contributing about $56 \%$ of total milk (110MT) produced by its varied population which is less than half that of the cattle population. Population size of Murrah is 20.49 million which constitutes $19.45 \%$ of the total buffalo population of India. Murrah buffalo is the most efficient milk producer and has better adaptability throughout India. The biggest limiting factor influencing the productivity of the buffaloes is the seasonality in displaying oestrus, conception rate and calving rate (Shah et al., 1989; Singh and Lal, 1994; Srivastava and Sahni, 1999). This may be the cause of the prolonged intercalving period 
since buffalo calving during the unfavorable season may not resume their ovarian activity until the following favorable season, decreasing their reproductive efficiency. Very limited information is available on the seasonal trend in the calving of the buffaloes so the objective of the study was to document the calving pattern of Murrah buffaloes in the Uttar Pradesh.

\section{Materials and Methods}

The study was conducted in Central plain of Uttar Pradesh (Etah and Unnao), Mid-western plain of Uttar Pradesh (Bareilly) and Western plain zone Uttar Pradesh (Meerut) of India on 2828Murrah buffaloes theses buffaloes were inseminated during June 2010 to December 2014at BAIF's field Artificial Insemination centers which provide door-step artificial insemination service at villages level.Keeping in view the climatological data, the year was divided into five seasons: winter (December to January), spring (February to April), summer (May to June), rainy (July to September) and autumn (October to November). Season categorization has been done as per reference and work over Seasonality Of Calving In Bhadawari And Murrah Buffaloes In Bundelkhand, India done by B.P. Kushwaha, Sultan Singh and S.B. Maity Buffalo Bulletin (December 2011).

\section{Results and Discussion}

When the data were grouped according to the various seasons, the highest percentage of calving (36) took place in the rainy (July to September) season, which was followed by the autumn (29) and the winter seasons (17). The lowest percentage (8) of calving was recorded in the spring season while $9 \%$ calving observed in summer season.
In the month wise study of calving study highest percentage of calving took place in the months of October and August 17 and15 percent, respectively followed by September, October and November 13,12 and 12 percent respectively. The carvings in the month of May, June and July was 4, 6 and 9 percent respectively. Lowest percentage of calving took place in the months of January, February, March, April 4, 3, 3 and 2 percent respectively. The results of the present study indicated that the rainy and the autumn seasons were the main calving seasons for Murrah buffaloes, when more than $65 \%$ of the calving took place.

The findings of the present study were in accordance with the findings of Hassan et al., (2007) and Hussain (2007) in Nili Ravi buffaloes in Pakistan. Anonymous (2008) also reported the main calving period between July to December in Murrah, Pandharpuri, Jaffrabadi and Surti buffaloes Haryana, Maharashtra, Gujrat and Rajasthan states, respectively. Sule et al., (2001) confirmed a distinct seasonality in breeding behavior in Surti buffaloes reared in Rajasthan. Reddy et al., (1999) also reported August to November the most favorable period for reproduction in Murrah buffaloes.

Agrawal (2003) reported that a determining factor in production and reproduction of farm animals all over the world is environment. Season affects the breeding efficiency, and buffaloes have tendency to performance better during the cool months; $70-80 \%$ of calvings in buffaloes occur between July and January. Misra and Sengupta (1965) reported that in India, the buffalo's sexual vigour declines during the summer and improves with the onset of the colder season. El-Sheikh (1987) reported more than $63 \%$ calvings occurred during the colder season in Egyptian buffaloes. 


\section{Calving observations in central zone}

Central zone of Uttar Pradesh is area of Unnao district. The District is roughly a parallelogram in shape and lies between Latitude $26^{\circ} 8^{\prime} \mathrm{N} \& 27^{\circ} 2^{\prime} \mathrm{N}$ and Longitude $80^{\circ} 3^{\prime} \mathrm{E} \& 81^{\circ} 3^{\prime} \mathrm{E}$. It is bounded on the North by District Hardoi. It has a subtropical climate (Köppen climate classification: Cfa) with hot summers and cool winters. The soil is mostly alluvial. The average temperature for the year is $25^{\circ} \mathrm{C}$. June, with an average temperature of $33^{\circ} \mathrm{C}$ is the warmest month, while the coolest month of the year is January, with an average temperature of $15^{\circ} \mathrm{C}$. When the data were grouped according to the various seasons, the highest percentage of calving (35) took place in the rainy season, which was followed by the autumn (33) and the winter seasons (17). The lowest percentage (7) of calving was recorded in the summer season while (8) calving observed in spring season. In the month wise study of calving study highest percentage of calving took place in the months of August and October15 and18 percent, respectively followed by November 12 percent. The calvings in the month of January, February, June, July, September and December month were 4, 5, 7, 12, 12 percent respectively. The lowest percentage of calving (2 to 3 ) took place in the months of March, April and May in the Murrah buffaloes.

\section{Calving observations in Mid-western plain zone}

Mid-western plain zone of Uttar Pradesh is area of Bareilly district. Bareilly is in northern India, at $28^{\circ} 10^{\prime} \mathrm{N} 78^{\circ} 23^{\prime} \mathrm{E}$. On its east are Pilibhit and Shahjahanpur. Bareilly has a humid subtropical climate (Köppen climate classification: Cfa) with hot summers and cool winters. The average temperature for the year is $25^{\circ} \mathrm{C}$. June, with an average temperature of $32.8^{\circ} \mathrm{C}$ is the warmest month, while the coolest month of the year is January, with an average temperature of $15^{\circ} \mathrm{C}$. When the data were grouped according to the various seasons, the highest percentage of calving (32) took place in the rainy season, which was followed by the autumn (29) and the winter seasons (20). The lowest percentage (8) of calving was recorded in the summer season while (10) calving observed in spring season. In the month wise study of calving study highest percentage of calving took place in the months of October and December 18 and 15 percent, respectively followed by September, November 12 percent. The calvings in the month of January, June, July, August month were 6, 5, 8 and 11 percent respectively. The lowest percentage of calving ( 3 to 4 ) took place in the months of February, March, April and May in the Murrah buffaloes.

\section{Calving observations in South Western Semi arid zone}

South Western Semi Arid zone of Uttar Pradesh is area of Etah district. The District is roughly a parallelogram in shape and located between $27.63^{\circ} \mathrm{N}$ and $78.67^{\circ} \mathrm{E}$ [5]. It has an average elevation of 170 metres (557 feet). Etah has a subtropical climate (Köppen climate classification: $\mathrm{Cfa}$ ) with hot summers and cool winters. The soil is mostly alluvial. The average temperature for the year is $25^{\circ} \mathrm{C}$. June, with an average temperature of $33^{\circ} \mathrm{C}$ is the warmest month, while the coolest month of the year is January, with an average temperature of $14^{\circ} \mathrm{C}$.

When the data were grouped according to the various seasons, the highest percentage of calving (39) took place in the rainy season, which was followed by the autumn (26) and the winter seasons (16). The lowest percentage (8) of calving was recorded in the summer season while (12) calving observed in spring season. In the month wise study of 
calving study highest percentage of calving took place in the months of August, September and October 15, 13 and13 percent, respectively followed by November, December 12 percent respectively. The carvings in the month of January, May June and July, were 5, 4, 8 and 10 percent respectively. The lowest percentage of calving took place in the months of February, March, April 3, 3 and 2 percent respectively.

\section{Calving observations in Western plain zone}

Western Plain zone of Uttar Pradesh is area of Merrut district. Meerut district lies between $28^{\circ} 57^{\prime}$ to $29^{\circ} 02^{\prime}$ North latitude and $77^{\circ} 40^{\prime}$ to $77^{\circ} 45^{\prime}$ East longitude in the Indo-Gangetic plains of India. It is bound on the north by Muzaffarnagar district, in the south by Bulandshahar district while Ghaziabad and Baghpat districts form the southern and western limits. Summers last from early April to late June during and are extremely hot, with temperatures reaching $49{ }^{\circ} \mathrm{C}$. The monsoon arrives in late June and continues till the middle of September. The average temperature for the year is $27^{\circ} \mathrm{C}$. June, with an average temperature of $33^{\circ} \mathrm{C}$ is the warmest month, while the coolest month of the year is January, with an average temperature of $14^{\circ} \mathrm{C}$.

When the data were grouped according to the various seasons, the highest percentage of calving (51) took place in the rainy season, which was followed by the autumn (24) and the winter seasons (8). The lowest percentage (4) of calving was recorded in the spring season while (12) calving observed in summer season. In the month wise study of calving study highest percentage of calving took place in the months of August, September and October 23,15,17 and 13 percent, respectively followed by November, December 7,8 percent respectively. The carvings in the month of May June and July, were 7, 5,13percent respectively. The lowest percentage of calving took place in the months of January, March, April 0.4,3 and 2 percent respectively (Table 1 and 2 ).

Table.1 Season and cluster wise number of observation

\begin{tabular}{|l|l|l|l|l|l|l|}
\hline CLUSTER & AUTOMAN & RAINY & SPRING & SUMMAR & WINTER & $\begin{array}{l}\text { Grand } \\
\text { Total }\end{array}$ \\
\hline CENTRAL & 356 & 375 & 88 & 78 & 178 & 1075 \\
\hline $\begin{array}{l}\text { MID WESTERN } \\
\text { PLAIN }\end{array}$ & 211 & 230 & 74 & 60 & 146 & 721 \\
\hline $\begin{array}{l}\text { SOUTH WESTERN } \\
\text { SEMI ARID }\end{array}$ & 205 & 310 & 61 & 95 & 132 & 803 \\
\hline WESTERN PLAIN & 55 & 117 & 10 & 28 & 19 & 229 \\
\hline Grand Total & 827 & 1032 & 233 & 261 & 475 & 2828 \\
\hline
\end{tabular}


Table.2 Month and cluster wise number of observations

\begin{tabular}{|c|c|c|c|c|c|}
\hline $\begin{array}{ll}\text { MONTH } & \text { OF } \\
\text { CALVING } & \\
\end{array}$ & CENTRAL & $\begin{array}{ll}\text { MIID } & \text { WESTERN } \\
\text { PLAIN } & \end{array}$ & $\begin{array}{l}\text { SOUTH WESTERN } \\
\text { SEMI ARID }\end{array}$ & $\begin{array}{l}\text { WESTERN } \\
\text { PLAIN }\end{array}$ & $\begin{array}{l}\text { Grand } \\
\text { Total }\end{array}$ \\
\hline 1 & 47 & 41 & 38 & 1 & 127 \\
\hline 2 & 44 & 25 & 25 & & 94 \\
\hline 3 & 26 & 19 & 22 & 6 & 73 \\
\hline 4 & 18 & 30 & 14 & 4 & 66 \\
\hline 5 & 29 & 22 & 32 & 16 & 99 \\
\hline 6 & 49 & 38 & 63 & 12 & 162 \\
\hline 7 & 80 & 61 & 82 & 30 & 253 \\
\hline 8 & 166 & 82 & 122 & 53 & 423 \\
\hline 9 & 129 & 87 & 106 & 34 & 356 \\
\hline 10 & 201 & 127 & 107 & 40 & 475 \\
\hline 11 & 155 & 84 & 98 & 15 & 352 \\
\hline 12 & 131 & 105 & 94 & 18 & 348 \\
\hline Grand Total & 1075 & 721 & 803 & 229 & 2828 \\
\hline
\end{tabular}

It is concluded as on the basis of season majority of calving observed between July to January months. It can be concluded that Murrah buffaloes have tendency to calve more in the days with shorter photoperiod as compare to days with longer photoperiod. The seasonality in calving observed in Murrah breed indicate that the photoperiodicity in different seasons plays a greater role than the diet, as these animals were maintained under an intensive system of management and fed properly throughout the year.

\section{Acknowledgments}

The authors are thankful to President, Senior Vice President, Management team of BAIF Development Research Foundation and all stakeholders in study area those who participated and cooperated during study

\section{References}

Agrawal, K.P. 2003. Augmentation of reproduction in buffaloes, p. 121. In
Proceedings of $4^{\text {th }}$ Asian Buffalo Congress lead paper.

El-Sheikh, A.S. 1987. The reproductive performance of the buffalo in Egypt. Indian J Dairy Sci.20: 8995.

Hassan, F., M.S. Khan, M.S. Rehman, M. Sarwarand S.A. Bhatti. 2007. Seasonality of calving in Nili-Ravi buffaloes, purebred sahiwal and crossbred cattle in Pakistan. Ital. J. Anim. Sci., 6(Suppl. 2), 1298-1301.

Hussain, Z. 2007. Seasonal variation in breeding and calving pattern of NiliRavi buffaloes in Azad Kashmir, Pakistan. Buffalo Bull., 26(4): 127-130.

Kushwaha B.P. Sultan Singh and S.B. 2011. Maity seasonality of calving in Bhadawari and Murrah buffaloes in Bundelkhand, India Buffalo Bulletin (December 2011) Vol. 30 No. 4.

Misra, M.S. and B.P. Sengupta. 1965. Climatic environment and reproductive behavior of buffaloes. III. Observations on semen quality of buffalo maintained under two different housing conditions. 
Indian J. Dairy Sci., 18:130-133

Shah, S.N.H., A.H. Willemese and D.F.M. Van deWiel. 1989. Influence of season and parity on several reproductive parameters on Nili-Ravi buffaloes in Pakistan. Anim. Reprod. Sci., 21:77190.

Singh, B. and K. Lal. 1994. Effect of season on the incidence of breeding and conception rate in buffaloes. Indian $J$. Anim. Sci., 64: 314-316.
Srivastava, S.K. and K.L. Sahni 1999. Effect of season on oestrus and conception in village cows and buffaloes. Indian Vet. J., 76(5): 385-387.

Sule, S.R., A.L., Taparia, L.S. Jain and S.P. Tailor. 2001. Reproductive status of Surti buffaloes maintained under subhumid conditions of Rajasthan. Indian Vet. J., 78(11): 1049-1051.

\section{How to cite this article:}

Potdar, V.V., J.R. Khadse, S.A. Joshi, Y.S. Gaundare, Marimuthu Swaminathan, N.L. Phadke and Pande, A.B. 2019. Seasonal Variation of Calving in Murrah Buffalo in different Agro Climatic Zones of Uttar Pradesh, India. Int.J.Curr.Microbiol.App.Sci. 8(05): 1234-1239. doi: https://doi.org/10.20546/ijcmas.2019.805.140 